\title{
The reality of the women who make our lives easier: experience in a company that assemblies electric motors in Venezuela
}

\author{
Yanes Escalona, $\mathrm{L}^{1}$, Sandia Venot, $\mathrm{R}^{1}$, Escalona, $\mathrm{E}^{1}$ and Yanes, $\mathrm{L}^{2}$ \\ ${ }^{I}$ Departamento de Salud Publica, Centro de Estudios en Salud de los Trabajadores, Universidad de Carabobo, \\ Av. Leonardo Ruiz Pineda. Universidad de Carabobo, Sede Aragua La Morita II. Maracay, Estado Aragua, \\ Venezuela. \\ ${ }^{2}$ Servicio Autónomo Instituto de Altos Estudios “Dr Arnoldo Gabaldon”. Ministerio del Poder Popular para la \\ Salud. Maracay, Estado Aragua. Venezuela.
}

\begin{abstract}
Objective: intervene a workline throughout ergonomic approach to diminish incidence of Carpal Tunnel Syndrome (CTS). Methods and Materials: an ergonomic intervention study was developed in workstations with highest index of musculoskeletal disorder (MED) associated to cumulative trauma. The Deparis method, Reba and Ocra check list methods were used, also morbility reviewes. National and international ethics criteria were carried out. Results: workers identified 3 fundamental issues using the Deparis method: repetitive activities, postures adopted and uncomfortable furniture. The analysis of the workstation with Reba and Ocra methods before the changes, evidenciated that $56 \%$ of postures adopted were high risk postures, the $44 \%$ remaining were medium and low-risk. Following the active pause program (APP), furniture changes and work rhythm decrease, was noted that the risk of suffering MED decreased. The morbility review, drop in consults of muscleskeletal system (MES) related to CTS observed. The APP was well accepted by women, but not initially men. Discussion: the research show that when the work rhythm decreases, the symptom of MES related to CTS have a remarkable decrease, also that changes in the furniture, generate great ergonomic differences and changes in the work environment are not possible if workers don't empower the tools to make-it.
\end{abstract}

Keywords: ergonomics; cumulative trauma disorders; carpal tunnel syndrome, electric motors assembly

\section{Introduction}

Have you ever asked yourselves how are the ergonomic conditions in the workplaces where the motors of blenders, washing machines and fans are assembled? Those things that make our lives easier, we will expose the situation of some of those workstations. Women are exposed to a variety of working conditions that could affect their health, well being and quality of life, in which we find the repetitive work of upper extremities, being one of the main consequences the Carpal Tunnel Syndrome, which not only limits their working live, but also in their family life.

Musculoskeletal disorders are a serious problem in the workplace. Manufacturing companies are not immune to this problem. This situation causes high costs in relation to health care, rehabilitation of injuries and days lost to medical leave in companies.

In Venezuela in recent years has become important to study the working conditions for corrective action of hazardous factors that may be affecting workers. Especially the ergonomic studies have increased from Work Environment Conditions and prevention Act (LOPCYMAT for its acronym in Spanish) reform in 2005 due to National Institute of Health and Safety Prevention (INPSASEL) provisions in their workplace inspections and penalties' that are applied to companies that incur in significant omissions regarding health and safety at work causing illnness or injuries.

In that sense, this research aims to answer specific ergonomic adjustments to allow a production line where a large group of workers have been affected by 
carpal tunnel syndrome in an electric motor assembly company and assess the changes implemented.

\section{Problem Description}

Recently, reports of repetitive motion injuries in the workplace have increased dramatically. These problems, which are often referred to as cumulative trauma disorders (CTD), are reported in all sort of workplaces, from meatpacking plants to newspaper printing press. In the past 15 years, has increased the case study of such disorders, especially carpal tunnel syndrome.

The repetitive trauma disorders represents $60 \%$ of all occupational diseases in the world according to the Centers for Disease Control and Prevention (CDC, for its acronym in English) and Bureau of Labor Statistics (National Institute for Occupational Safety and NIOSH Occupational Health, 1997). 90\% are women engaged in trades such as styling, typing and other that imply hand precision. Among them, carpal tunnel syndrome is the condition most frequently reported.

Musculoskeletal disorders are one of the most important issues regarding occupational health globally and in Venezuela. It is one of the most important causes of absenteeism.

In Venezuela, INPSASEL reported in 2006, 2066 diagnoses of occupational diseases, of which, $77 \%$ cases were musculoskeletal disorders. In manufacturing in the same period were diagnosed 845 cases of musculoskeletal diseases, accounting for $53 \%$ of all diagnosed cases, ranking the first place according to the distribution of economic activity in our country.

Morbidity records of the medical service in the Electric Motor Factory reflect the musculoskeletal disorders as one of the main reasons for consultation and cause of absenteeism from all production lines.

In $2006,51.6 \%$ of all diagnoses issued by the company were represented by musculo-skeletal disorders (MOTORVENCA, 2006). Of these 36\% belong to the Oster engine assembly line; the same year 25 cases of Carpal Tunnel Syndrome were confirmed.

\section{Objective}

The objective of this investigation was to intervene the Oster work line throughout ergonomic approach to diminish the incidence of Carpal Tunnel
Syndrome. In order to do the investigation we analyzed 17 workstations and their workers.

\section{Methods and materials}

\section{Selection of workstations}

This study was conducted in a company that manufactures electric motors, and included the OSTER Line workstations $(\mathrm{n}=6)$, which were selected doe to that they had the highest index of muscle skeletal disorder, associated to cumulative trauma.

The Deparis method modificated by Escalona (Escalona et al, 2008), Reba (S. Hignett y L. McAtamney 2000); and Ocra check list (Colombini, Occhipinti, \& Grieco, 2000) methods were used, we also reviewed the morbidity of the workers through the whole study.

This research carried out the national and international ethics criteria methods.

\section{Results}

REBA and OCRA methods

\begin{tabular}{|l|c|c|c|c|}
\hline & \multicolumn{2}{|c|}{ Before } & \multicolumn{2}{c|}{ After } \\
\hline Workstation & $\begin{array}{c}\text { REBA } \\
\text { index }\end{array}$ & $\begin{array}{c}\text { OCRA } \\
\text { index }\end{array}$ & $\begin{array}{c}\text { REBA } \\
\text { index }\end{array}$ & $\begin{array}{c}\text { OCRA } \\
\text { index }\end{array}$ \\
\hline $\begin{array}{l}\text { Colocar } \\
\text { Portacarbón }\end{array}$ & 2 & 19 & 2 & 10 \\
\hline Probar motor & 2 & 7,5 & 2 & 7,5 \\
\hline Colocar sellos & 5 & 13 & 4 & 9 \\
\hline Armar colmena & 2 & 8 & 2 & 7 \\
\hline Armar Caja & 3 & 11 & 3 & 9 \\
\hline Embalar & 5 & 14 & 4 & 10 \\
\hline
\end{tabular}

It is clear in the table presented that after the implementation of the different recommendations (changes in the furniture, specifically chairs and foot rest, and the implementation of the Active Pause Program as the reduction of the work rhythm the risks levels of developing musculoskeletal disorders evaluated with REBA and OCRA methods diminished.

DEPARIS method modificated by Escalona et al

After the collective interviews of the workers that labored in the different workstation of the assembly line, it was evident that the items less satisfactory were $\mathrm{N}^{\mathrm{o}} 3,7,9,15$ and 19.

These items were taken as a guideline to implement the changes of the workstations according to the priorities chosen by the workers, in order to make sure that the suggestions and criteria of the workers would prevail. 
Regarding the work organization the problems identified in the organization of production, especially in relation to the production demands, material handling and provision and arrangement of components, inputs and outputs of each stage. This situation is common in all the workstations.

\begin{tabular}{|c|c|c|c|c|c|c|}
\hline & \multicolumn{6}{|c|}{$\begin{array}{c}\text { Work line OSTER } \\
\text { Subline Engine } \\
\text { Ensamble }\end{array}$} \\
\hline & 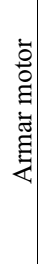 & 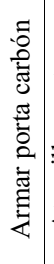 & 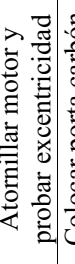 & 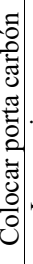 & 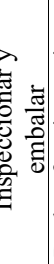 & 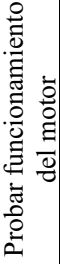 \\
\hline 1. Workplace & & & & & & \\
\hline 2. Organization between worstations & & & & & & \\
\hline 3. Adapting work & & & & & & \\
\hline 4. Accidents & & & & & & \\
\hline 5. Commands and Signs & & & & & & \\
\hline 6. Work tools & & & & & & \\
\hline 7. Repetitive work & & & & & & \\
\hline 8. Lifting conditions & & & & & & \\
\hline 9. Mental load & & & & & & \\
\hline 10. Lighting & & & & & & \\
\hline 11. Noise & & & & & & \\
\hline 12. Thermal enviroment & & & & & & \\
\hline 13. Chemical pollution & & & & & & \\
\hline 14. Vivrations & & & & & & \\
\hline 15. Peer relations & & & & & & \\
\hline 16. General and local social enviroment & & & & & & \\
\hline 17. Work content & & & & & & \\
\hline 18. Psicosocial enviroment & & & & & & \\
\hline 19. Pain areas at the end of journey & & & & & & \\
\hline
\end{tabular}

\section{Discussion}

The research proved that when the work rhythm is decreased and allowing the resting of the upper limb used musculature, the symptom of muscle skeletal system related to Carpal Tunnel Syndrome have a remarkable decrease, also that small changes in the furniture, generate great differences in which ergonomics is concerned and that changes in the work environment are not possible if the workers don't empower the tools to carry them out.

\section{References}

[1]Colombini, D., Occhipinti, E. \& Grieco, A. (2000). OCRA. A check-list model for the quick evaluation of risk exposure (ocra index). Extraído el 8 de Septiembre de 2010 Disponible en:

http:// www.ergonautas.upb.es/metodos/ocra/ocra-ayuda.php

[2]Escalona E. Yanes L.J., Yanes L., Sandia R y Yanes A. Ergonomía y participación de los trabajadores y trabajadoras en el diagnóstico de las condiciones de trabajo en una empresa de motores eléctricos en Venezuela. Ponencia presentada y publicada en extenso en el Proceding CD Room del $6^{\circ}$ Congreso Internacional de Riesgos Laborales. La Coruña. España. 14 al 18 de Mayo de 2008

[3]Monique Noulin, 1992. Metodología de intervención ergonómica: una visión contemporánea para la prevención de riesgos desde la ergonomía centrada en la actividad.

[4]Sindrome del Tunel Carpiano. Recuperado el 17 de junio de 2010, de Centro de Control y Prevencion de Enfermedades de atlanta: http://www.cdc.gov/spanish/niosh/factsheets/Fact-sheet-705001.html

[5]Motorvenca, S. M. (2006). Morbidity records . Villa de Cura.

[6]Hignett, S. y McAtamney, L., 2000, REBA: Rapid Entire Body Assessment. Applied Ergonomics, 31, pp.201-205. Reviewd 